\title{
EFFECT OF HYPNO BREASTFEEDING ON COLOSTRUM EJECTION ONSET IN PRIMIPAROUS MOTHERS
}

\author{
Nur Masruroh, Ratna Ariesta Dwi Andriani \\ Faculty of Nursing and Midwifery, \\ Universitas Nahdlatul Ulama, Surabaya
}

\begin{abstract}
Background: Hypno breastfeeding technique is a natural effort to use subconscious energy given to postpartum mothers so that the breastfeeding process runs safely and smoothly. This effort is done by entering positive affirmation or suggestion when the mother is very relaxed or very concentrated on a goal so that mother can produce enough milk for the infants growing needs. This study aimed to analyze effect of hypno breastfeeding on colostrum ejection onset in primiparous mothers.

Subjects and Methods: This was a quasi experiment (non-randomized) after only with control design conducted at two Puskesmas (Community Health Center), Surabaya, East Java. A sample of 60 primiparous mothers were selected and allocated in two groups: 30 mothers undergoing hypno breastfeeding and 30 mothers not undergoing hypno-breastfeeding. The dependent variable was onset of colostrum ejection. The independent variable was hypno breastfeeding. The data were collected by observation and interview. The data were analyzed by a ttest.

Results: Onset of colostrum ejection was shorter in the hypno breastfeeding group (mean=13.2; $\mathrm{SD}=2.1$ ) than the control group (mean=15.7; $\mathrm{SD}=1.9)$, but it was statistically non-significant.

Conclusions: Hypno breastfeeding shortens onset of colostrum ejection but it was statistically non-significant.
\end{abstract}

Keywords: hypno breastfeeding, colostrum ejection, onset, primiparous mothers

\section{Correspondence:}

Nur Masruroh. Faculty of Nursing and Midwifery, Universitas Nahdlatul Ulama, Surabaya, East Java. Email: masruroh@unusa.ac.id. Mobile: +6281332630941. 